\title{
Dinamika Sikap Tiongkok atas Putusan Mahkamah Arbitrase Tetap Internasional Nomor 2013-19 dan Pengaruhnya terhadap Indonesia
}

\author{
Ayu Megawati \\ University of Jember, Indonesia \\ aw.mhey@gmail.com
}

\author{
Gautama Budi Arundhati \\ University of Jember, Indonesia \\ arundhati_rev_gb@yahoo.co.id
}

\section{ABSTRACT}

The Conflict in South China Sea involves several countries in Southeast Asia, such as the Philippines, Vietnam, Malaysia, Brunei Darussalam, and Indonesia. It is dealt with the rights of ownership, as a result of the People Republic of China (PRC) to unveil nine-dashed line which partially claims over South China Sea. But, it is followed by other countries to release new evidences on the territorial status of South China Sea. Though the Permanent Court of Arbitration had decided the petition of the Philippines in 2013, PRC could not admit the Arbitration. Essentially, Indonesia is not directly involved in the case. But as the evidence provided by PRC, Natuna Islands is part of nine-dashed line in which it asserts that such islands are regarded part of PRC. As a result, Indonesia needs to anticipate on the further potential contention of territorial claims as it has islands around the South China Sea.

KEYWORDS: South China Sea Dispute, Permanent Court of Arbitration.

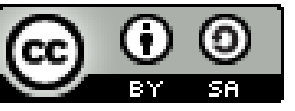

Copyright $\odot 2018$ by Author(s)

This work is licensed under a Creative Commons Attribution-ShareAlike 4.0 International License. All writings published in this journal are personal views of the authors and do not represent the views of this journal and the author's affiliated institutions.

\section{HOW TO CITE:}

Megawati, Ayu \& Gautama Budi Arundhati. "Dinamika Sikap Tiongkok atas Putusan Mahkamah Arbitrase Tetap Internasional Nomor 2013-19 dan Pengaruhnya terhadap Indonesia” (2018) 5:1 Lentera Hukum 31-46.

Submitted: January 16, 2018 Revised: February 22, 2018 Accepted: March 12, 2018 


\section{PENDAHULUAN}

Tulisan ini membahas sikap Republik Rakyat Tiongkok (RRT) pasca putusan tribunal mengenai sengketa yang diajukan Filipina pada 2013 lalu mengenai klaim RRT di Laut China Selatan. Putusan yang dikeluarkan tribunal pada Juli 2016 lalu telah memberikan gambaran yang cukup signifikan atas aktifitas RRT di Laut China Selatan. Namun sikap RRT tidak menunjukkan kepatuhan selama proses peradilan hingga tribunal mengeluarkan putusan tersebut. Sehingga perlu dikaji bagaimana akibat hukum adanya putusan tribunal itu terhadap stabilitas kawasan. Di samping itu, secara tidak langsung kawasan yang di klaim RRT melalui sembilan garis putus-putus (nine dash line) itu menimbulkan tumpang tindih dengan wilayah negara sekitar termasuk Indonesia di Laut Natuna.

Menyikapi hal tersebut, Indonesia bersama dengan negara anggota ASEAN lainnya berusaha meningkatkan komunikasi melalui jalur diplomasi untuk menetralisir situasi dan selanjutnya dapat membangun kembali hubungan ke arah yang lebih harmonis. dimana solidaritas ASEAN sebagai organisasi regional tengah diuji untuk menerapkan norma-norma regional dan kebiasaan-kebiasaan regional, seperti keterlibatan secara multilateral. Melihat posisi Indonesia dan RRT yang berdekatan secara geografis, menjadi sangat penting secara geopolitik bagi kedua negara ini untuk menjalin hubungan yang baik meski dalam beberapa kesempatan RRT tidak menyinggung persoalan tumpang tindih klaim kawasan dengan Indonesia namun Indonesia tetap harus bersikap tegas terhadap posisinya. Karena sikap RRT tersebut akan memberikan dampak terhadap Indonesia dan stabilitas keamanan di ASEAN.

\section{IMPLIKASI PUTUSAN MAHKAMAH ARBITRASE TETAP INTERNASIONAL TENTANG SENGKETA LAUT CHINA SELATAN}

Kedaulatan atas Laut China Selatan telah banyak menarik perhatian negara-negara sekitar, hal ini dimulai sejak berakhirnya perang dunia ke II. Pada saat itu Perjanjian Damai San Fransisco 1951 tidak menentukan secara spesifik wilayah Kepulauan Spratly dan siapa yang berhak menerima kedaulatan pasca dilepas oleh Jepang. ${ }^{1}$ Hal tersebut kemudian menimbulkan kekosongan kekuasaan geopolitik. Di samping itu, juga menyebabkan terjadinya klaim tumpang tindih antara negara-negara sekitar seperti Filipina, Malaysia, Brunei Darussalam, Vietnam dan RRT termasuk Taiwan, ${ }^{2}$ yang mendasarkan klaim menurut kebenaran yang dianut masing-masing negara.

\footnotetext{
Masahiro Matsumura, "San Francisco Treaty and the South China Sea”, Jpn Times (13 October 2013), online: 〈https://www.japantimes.co.jp/opinion/2013/10/13/commentary/world-commentary/sanfrancisco-treaty-and-the-south-china-sea/s.

2 Stefan Talmon \& Bing Bing Jia, The South China Sea Arbitration: A Chinese Perspective (Bloomsbury Publishing, 2014) at 1.
} 
Ada kesamaan dan perbedaan antara situasi di LCS dan Asia Timur Laut. ${ }^{3}$ Seperti halnya LCS, bahwa di kawasan laut tersebut terdapat wilayah territorial dan kedaulatan antar negara-negara sekitar. Namun, sengketa teritorial dan kedaulatan LCS lebih multilateral daripada perselisihan teritorial di Asia Timur Laut, yang sebagian besar bersifat bilateral, yang pada intinya sengketa teritorial dan kedaulatan di LCS menyangkut Kepulauan Paracels dan Spratlys. Di Asia Timur Laut, yakni termasuk Kepulauan Diaoyutai (Senkaku) antara RRT/Taiwan dan Jepang, pulau Tokdo (Takeshima) antara Korea dan Jepang dan empat Wilayah Utara (Kurade Selatan) antara Jepang dan Federasi Rusia. ${ }^{4}$ Sebagai hasil dari sengketa kepemilikan pulau-pulau ini, adanya kesulitan yang kemudian muncul sehubungan dengan penentuan batas laut antar negara-negara yang bersangkutan.

Pada sengketa di LCS dan Asia Timur Laut terdapat isu yang terbagi antara RRT dan Korea, meskipun pada kenyataannya terjadi persaingan antara RRT dan Taiwan untuk saling menonjolkan diri dalam upaya untuk mengelola potensi konflik di wilayah tersebut. ${ }^{5}$ Oleh karena itu peran RRT sangat penting di kedua wilayah. Upaya untuk merumuskan pembangunan bersama telah menghasilkan kesepakatan antara Jepang dan Korea Selatan, namun tidak ditemukan hidrokarbon di wilayah tersebut dan kemudian kesepakatan tersebut juga ditentang dan diprotes oleh RRT. ${ }^{6}$ Di LCS, upaya untuk mencari solusi melalui pengembangan bersama cukup berhasil. Hal tersebut dapat dilihat terutama antara Malaysia dan Thailand, Malaysia dan Vietnam, keduanya tanpa melibatkan RRT. ${ }^{7}$ Thailand, Malaysia dan Vietnam memiliki itikad hubungan politik yang kuat untuk mencari solusi yang terbaik karena keterlibatan negara-negara tersebut sebagai anggota ASEAN.. Sementara RRT selalu mengaku bersedia untuk mengesampingkan sengketa kedaulatan teritorial dan mendukung pengembangan yang mengikat di LCS, kenyataannya tidak mudah untuk memahami apa yang sebenarnya dimaksudkan oleh RRT yakni pengembangan bersama dan mengelola sengketa kedaulatan teritorial.

Pengelolaan sengketa kedaulatan territorial tidak dapat serta-merta mengikuti kehendak salah satu pihak tanpa persetujuan pihak lainnya. Dalam pengelolaan sengketa kedaulatan territorial banyak cara yang dapat dilakukan dan sesuai dengan hukum Internasional, salah satu penyelesaian sengketa internasional yakni melalui Arbitrase. ${ }^{8}$ Arbitrase telah lama menjadi pilihan penyelesaian sengketa. Arbitrase yang

3 Negara Asia Timur Laut yakni meliputi Jepang, China, Korea Selatan, dan Korea Utara, lebih lengkapnya lihat secara umum pada Scott Snyder \& See-Won Byun, "Cheonan And Yeonpyeong: The Northeast Asian Response to North Korea's Provocations" (2011) 156:2 RUSI J 74.

4 Mengenai sengketa territorial di kawasan Asia Timur Laut lihat pada Paul O'Shea, "Territorial disputes in Northeast Asia: A primer" (2013) 182 Ital Inst Int Polit Stud Anal ISPI No 182.

5 Lihat secara umum pada Maritime Zone of Northeast Asia, CIA-RPD08C01297R000200130003-5 (Bureau of Intelligence and Research of Central Intelligence Agency US, 2012).

6 Ibid.

7 Perlu kita ingat bahwa negara-negara anggota ASEAN memiliki prinsip solidaritas yang tinggi dalam upaya menyelesaikan sengketa di kawasan. Lihat pada Gautama Budi Arundhati, "Dinamika Relasi Antara Prinsip Non Interference dan Prinsip Solidaritas ASEAN" (2017), online: 〈http://repository.unej.ac.id/handle/123456789/79234〉 at 100.

8 Sri Setianingsih Suwardi, Penyelesaian Sengketa Internasional (Jakarta: UI-Press, 2006) at 39. 
diajukan Filipina kepada Tribunal adalah tentang penafsiran dari pasal-pasal yang terdapat dalam UNCLOS 1982 serta posisi RRT dalam melakukan aktivitasnya di LCS. ${ }^{9}$ Akan tetapi ketika putusan tersebut keluar pada 2016 lalu, RRT menganggap bahwa putusan tersebut adalah batal demi hukum. ${ }^{10}$

Perlu kita ketahui bahwa terdapat empat kategori yang disimpulkan oleh Tribunal atas pengajuan Filipina. Pertama, Filipina telah meminta Tribunal untuk menyelesaikan perselisihan antara Para Pihak mengenai sumber hak dan hak maritim di LCS. ${ }^{11}$ Secara khusus, Filipina mencari sebuah deklarasi dari Tribunal mengenai hak RRT di LCS berdasar pada Konvensi dan tidak memiliki hak untuk mengklaim hak historis apapun. Dalam hal ini, Filipina mencari sebuah kebenaran terhadap klaim RRT terhadap hak-hak di dalam nine dash line yang ditandai pada peta RRT tidak memiliki kekuatan hukum yang sah sejauh mereka melampaui hak yang diizinkan RRT oleh Konvensi. Kedua, Filipina telah meminta Tribunal untuk menyelesaikan perselisihan antara Para Pihak mengenai hak-hak tersebut ke zona maritim yang akan dihasilkan berdasarkan Konvensi pada Scarborough Shoal dan beberapa fitur maritim tertentu di Kepulauan Spratly yang diklaim oleh Filipina dan RRT. ${ }^{12}$ Konvensi tersebut menetapkan bahwa bagian-bagian yang terendam dan ketinggian air surut tidak mampu menghasilkan hak apapun ke wilayah maritim. Kemudian bahwa hutan yang tidak dapat menopang hunian atau kehidupan ekonomi mereka sendiri tidak menghasilkan hak zona ekonomi eksklusif sejauh $200 \mathrm{Nm}$ (nautical miles/mil laut) ataupun landas kontinen. ${ }^{13}$

Filipina mencari sebuah deklarasi dimana semua fitur yang diklaim oleh RRT di Kepulauan Spratly dan Scarborough Shoal, termasuk dalam satu atau kategori lainnya menyatakan tidak satu pun dari fitur ini menghasilkan sebuah Hak atas zona ekonomi eksklusif atau landas kontinen. Ketiga, Filipina telah meminta Tribunal untuk menyelesaikan serangkaian perselisihan antara Para Pihak mengenai keabsahan tindakan RRT di LCS. ${ }^{14}$ Filipina mencari deklarasi bahwa RRT telah melanggar Konvensi. Deklarasi tersebut adalah mengenai aktivitas RRT yang mencampuri pelaksanaan hak Filipina berdasarkan Konvensi, termasuk berkenaan dengan penangkapan ikan, eksplorasi minyak, navigasi, dan pembangunan pulau dan instalasi

9 Lihat secara umum PCA Case No 2013-19 In Matter of The South China Sea Arbitration before an Arbitral Tribunal Constituted Under Annex VII to The 1982 United Nations Convention on The Law of The Sea Between The Republic of Philippines and The People's Republic of China [PCA Case No 2013-19]; R Ridderhof, "The South China Sea Arbitration (12 July 2016) PCA Case No. 2013-19 | Peace Palace Library”, (22 July 2017), online: 〈//www.peacepalacelibrary.nl/2016/07/pca-award-south-china-sea-12-july-2016/>.

10 Lihat pernyataan RRT pada position paper yang dikeluarkan di tengah-tengah persidangan berlangsung dalam Position Paper of the Government of the People's Republic of China on the Matter of Jurisdiction in the South China Sea Arbitration Initiated by the Republic of the Philippines [Position Paper of the People's Republic of China].

Il Lihat secara umum pada PCA Case No 2013-19, supra note 9.

12 Ibid.

13 Lihat mengenai zona ekonomi eksklusif dan landas kontinen yang telah termaktub dalam hukum internasional pada United Nation Convention on the Law of the Sea 1982 [United Nation Convention on the Law of the Sea 1982] at 45.

14 Lihat secara umum pada PCA Case No 2013-19, supra note 9. 
buatan. ${ }^{15}$ Hal tersebut kemudian menjadi penyebab RRT gagal untuk melindungi dan melestarikan lingkungan laut. Karena dengan aktifitasnya di LCS yang memberikan toleransi dan secara aktif mendukung nelayan Tiongkok dalam memanen spesies yang terancam punah dan penggunaan metode penangkapan ikan yang membahayakan maka akan merusak ekosistem terumbu karang yang rapuh di LCS. ${ }^{16}$

Lalu apa yang dilakukan RRT di kawasan tersebut menimbulkan kerusakan pada lingkungan laut dengan membangun pulau-pulau buatan dan terlibat dalam reklamasi lahan yang ekstensif di tujuh terumbu karang di Kepulauan Spratly. Keempat, Filipina telah meminta Tribunal untuk menemukan analisis hukum bahwa RRT telah memperburuk dan memperpanjang perselisihan antara Para Pihak selama Arbitrasi ini dengan membatasi akses terhadap detasemen marinir Filipina yang ditempatkan di Thomas Shoal Kedua yang melibatkannya dalam konstruksi pulau buatan dan reklamasi skala besar di tujuh terumbu karang di Kepulauan Spratly.

Dari alasan Filipina yang telah dijelaskan diatas dapat kita ketahui bahwa kewenangan PCA secara umum adalah untuk menyelesaikan sengketa secara damai berdasar Konvensi tahun 1899 dan tahun 1907 tentang International Pacific Settlement Dispute. ${ }^{17}$ Secara khusus kewenangan PCA dalam sengketa ini adalah untuk menafsirkan hal-hal yang diatur dalam UNCLOS 1982 yakni mengenai karang, pulau, serta keabsahan aktifitas RRT di LCS berdasar UNCLOS 1982. ${ }^{18}$ Tribunal menggunakan dasar Konvensi Perserikatan Bangsa-Bangsa tentang Hukum Laut 1982 dalam menjalankan peradilan ini. Termasuk pula dalam penerapan prinsip "jika salah satu pihak tidak datang dalam persidangan maka dapat tetap dilanjutkan". ${ }^{19}$ Hal inilah yang mendasari tetap dilaksanakannya peradilan meskipun pihak RRT tidak menghadiri persidangan dari awal. Padahal kedua pihak telah menjadi bagian dari Konvensi tersebut. Filipina meratifikasinya pada tanggal 8 Mei 1984 dan RRT meratifikasi pada tanggal 7 Juni $1996 .^{20}$ Kemudian konvensi tersebut diadopsi oleh negara-negara anggota sebagai undang-undang yang mengatur tentang lautan dan memiliki tujuan untuk menyelesaikan semua masalah yang berkaitan dengan hukum laut. Konvensi ini membahas berbagai isu dan mencakup sebagai bagian integral sebuah

15 Ibid.

16 Ibid.

17 Lihat Chapter VI Charter of the United Nations, U N Charter, 1945 [UN Charter] at 8; James Brown Scott, The Hague Court Reports [1st]-2nd Series: Comprising the Awards, accompanied by Syllabi, the Agreements for Arbitration, and Other Documents in Each Case Submitted to the Permanent Court of Arbitration and to Commissions of Inquiry Under the Provisions of the Conventions of 1899 and 1907 for the Pacific Settlement of International Disputes (Oxford University Press, American branch, 1916); Mark Weston Janis, "The Hague Peace Conferences of 1899 and 1907 and International Arbitration: Reports and Documents" (2002) 49:2 Neth Int Law Rev 290.

18 PCA Case No 2013-19, supra note 9.

19 Meski RRT tidak pernah berpartisipasi secara formal selama proses persidangan berlangsung, namun persidangan tetap berjalan hingga akhir. Lihat Annex VII UNCLOS 1982 United Nation Convention on the Law of the Sea 1982, supra note 13.

20 Sejauh ini terdapat 168 negara yang telah meratifikasi UNCLOS 1982 termasuk Filipina, RRT, dan Indonesia. "Chronological lists of ratifications of", online: 〈http://www.un.org/depts/los/reference_files/chronological_lists_of_ratifications.htm〉. 
sistem untuk penyelesaian sengketa damai. Sistem ini tercantum dalam Bagian XV Konvensi yang menyediakan berbagai prosedur penyelesaian sengketa, termasuk arbitrase wajib sesuai dengan prosedur yang tercantum dalam Lampiran VII pada Konvensi. $^{21}$

Konvensi tersebut, bagaimanapun, tidak membahas kedaulatan negara atas wilayah darat. Oleh karenanya Tribunal tidak diminta untuk, dan tidak bermaksud, membuat keputusan mengenai negara mana yang berhak atas kedaulatan wilayah darat di LCS, khususnya sehubungan dengan sengketa mengenai kedaulatan atas Kepulauan Spratly atau Kepulauan Scarborough. Tidak satu pun dari keputusan Tribunal tersebut yang menetapkan kedaulatan suatu negara, atau apa pun dalam putusan ini dipahami untuk menyiratkan pandangan sehubungan dengan pertanyaan tentang kedaulatan daratan. ${ }^{22}$

Demikian pula, walaupun Konvensi tersebut memuat ketentuan mengenai pembatasan batas laut, RRT membuat sebuah deklarasi pada tahun 2006 untuk mengecualikan pembatasan batas laut dari penerimaan penyelesaian sengketa wajib, sesuatu yang secara tegas diizinkan oleh Konvensi mengenai batas-batas maritim dan beberapa hal lainnya. ${ }^{23}$ Oleh karenanya Pengadilan tersebut belum diminta untuk, dan tidak bermaksud untuk membatasi batas maritim antara Para Pihak atau melibatkan negara lain yang berbatasan dengan LCS. Sejauh ini wilayah yang diklaim Filipina berkaitan dengan klaim tumpang tindih di bagian LCS. Berdasar hal tersebut Pengadilan hanya menyelesaikan sengketa sejauh hak dan kewajiban masing-masing pihak dimana hal itu tidak berhubungan pada batas laut atau tidak berkaitan dengan sebuah penetapan batas wilayah agar sesuai dengan penerapan Konvensi yang tidak menghasilkan tumpang tindih atas hak-hak pada masing-masing pihak.

Selama persidangan berlangsung RRT mengadopsi posisi non-penerimaan dan non-partisipasi, yakni menolak untuk berpartisipasi sejak awal. Namun keputusan tersebut harus dihormati oleh negara lain karena hal ini sah menurut hukum internasional, terutama UNCLOS. Alasan sikap RRT tersebut bahwa arbitrase tidak memiliki yurisdiksi untuk menyelesaikan perkara. ${ }^{24}$ Akan tetapi keputusan yang diambil tidak mencegah berlangsungnya arbitrase. Hal itu berada dalam kerangka hukum internasional bahwa arbitrase dapat membuat keputusannya setelah memenuhi persyaratan bahwa ia memiliki yurisdiksi dan bahwa klaim tersebut telah ditetapkan dengan baik.

Terlepas dari keputusannya untuk tidak tampil secara formal dalam hal apapun dalam proses tersebut, RRT telah mengambil langkah-langkah yang secara informal memperjelas anggapannya bahwa Pengadilan tersebut tidak memiliki yurisdiksi untuk

$21 \quad$ Lihat secara umum pada bagian XV UNCLOS 1982 mengenai penyelesaian sengketa secara damai United Nation Convention on the Law of the Sea 1982, supra note 13.

22 Lihat PCA Case No 2013-19, supra note 9.

23 Lihat Ridderhof, supra note 9; Talmon \& Jia, supra note 2; PCA Case No 2013-19, supra note 9.

24 "How China can benefit from the S. China Sea arbitration - Opinion - The Jakarta Post", online: 〈http://www.thejakartapost.com/academia/2016/06/16/how-china-can-benefit-from-the-s-china-seaarbitration.html>. 
mempertimbangkan klaim Filipina manapun. Pada tanggal 7 Desember 2014, Kementerian Luar Negeri RRT menerbitkan kertas posisi mengenai masalah yurisdiksi pada proses Arbitrase LCS yang diprakarsai oleh Republik Filipina. ${ }^{25}$ Dalam hal itu RRT berpendapat bahwa Tribunal tidak memiliki yurisdiksi karena esensi pokok masalah arbitrase adalah kedaulatan teritorial atas fitur maritim yang relevan di LCS. Kemudian pada kertas posisi tersebut RRT menyatakan bahwa kedua pihak telah sepakat untuk menyelesaikan perselisihan terkait melalui instrumen bilateral yakni sebuah perundingan.

Kertas Posisi yang dikeluarkan oleh RRT tersebut pada prinsipnya mempertanyakan kompetensi arbitrase karena inti penyampaian Filipina berkaitan dengan kedaulatan dan pembatasan. Sampai batas tertentu, perselisihan itu terkait dengan delimitasi dan kedaulatan, namun arbitrase sangat berhati-hati. Dalam penghargaannya atas yurisdiksi tahun lalu, pengadilan tersebut tidak menegaskan yurisdiksi untuk mendengarkan kasus tersebut ke semua pengajuan, namun mencadangkan haknya untuk menentukan yurisdiksi setelah mendengar argumen mengenai kelebihan mereka. Arbitrase sebenarnya telah bertindak adil dan tidak memihak. Argumen Duta Besar Xie Feng bahwa arbitrase telah menolak untuk kemudian memberikan pengesahan document of conduct yang mengikat secara hukum (DOC) di LCS yang cacat secara hukum. ${ }^{26}$

Dalam kertas posisinnya, RRT menyatakan bahwa DOC bukan dokumen hukum, namun merupakan dokumen politik. Dengan demikian, DOC tidak memiliki kekuatan yang mengikat secara hukum. Selanjutnya DOC bertujuan untuk mengatur perilaku dan mengelola perselisihan, sedangkan materi arbitrase menyangkut interpretasi dan penerapan ketentuan UNCLOS. Terakhir, DOC berlaku untuk seluruh wilayah LCS sementara arbitrase hanya menyangkut area yang terkait dengan klaim Filipina. Ketiga, mengenai sikap para pihak dalam mematuhi keputusan arbitrase. Kedua pihak baik RRT maupun Filipina sebagai pihak dalam perselisihan tersebut tetap berada di bawah kewajiban internasional untuk mematuhi keputusan arbitrase. ${ }^{27}$

Sampai saat ini, RRT telah menyatakan tentangannya yang kuat dan tidak akan mengikuti keputusan arbitrase. Langkah tersebut tentu menciptakan ketegangan dan ketidakstabilan di LCS. Jadi banyak yang dipertaruhkan jikaRR memutuskan untuk tidak mengikuti keputusan tersebut. Ini akan menjadi pukulan balasan terhadap peraturan hukum dan menunjukkan contoh negatif bagaimana tindakan sepihak tanpa dasar menemukan tempatnya di masyarakat internasional. Contoh seperti itu tidak diharapkan dari anggota tetap Dewan Keamanan PBB. RRT sebagai pemrakarsa sistem peradilan internasional dapat dilihat oleh fakta bahwa selalu ada hakim dari RRT di Pengadilan Internasional (ICJ) dan Pengadilan Internasional untuk Hukum Laut

\footnotetext{
25 RRT mengeluarkan position paper pada 7 Desember 2014 dimana pada 22 April 2015, panel arbitrase memutuskan bahwa position paper tersebut sebagai argument RRT mengenai yurisdiksi dari arbitrase. Lihat Position Paper of the People's Republic of China, supra note 104.

26 Ibid.

27 PCA Case No 2013-19, supra note 9.
} 
(ITLOS). ${ }^{28}$ Di bawah Pembukaan Piagam PBB, kami berjanji untuk menetapkan kondisi di mana keadilan dan penghormatan terhadap kewajiban yang timbul dari perjanjian dan hukum internasional dapat dipertahankan. Sebagai anggota tetap Dewan Keamanan, RRT harus memimpin dengan memberi contoh dalam penegakan supremasi hukum. RRT seharusnya tidak mendapat jaminan dan menarik diri dari UNCLOS.

Perselisihan yang diajukan oleh Filipina merupakan bagian integral dari pembatasan maritim antara kedua negara. Sementara pada saat yang sama menjelaskan bahwa komunikasi semacam itu seharusnya tidak ditafsirkan sebagai partisipasi RRT dalam proses arbitrase. Namun tribunal menganggapnya sebagai argumen RRT mengenai yurisdiksi dari arbitrase yang sedang dijalankan. ${ }^{29}$ Selama kasus tersebut naik ke PCA, RRT begitu gencamelancarkan proyek raksasa berupa serangkaian pulau buatan guna menampung sejumlah pangkalan militer. Hal tersebut diindikasikan untuk menciptakan faith-accomply $y^{30}$ atas putusan PCA di Den Haag. Selain itu, pulau tersebut berfungsi untuk memperkuat klaim kedaulatan RRT serta menjadi wadah keberadaan RRT di ranah militer dan sipil.

Sama pentingnya dengan langkah hukum yang telah dilakukan oleh Filipina, keefektifannya masih harus dilihat. Sebagaimana yang telah ditunjukkan oleh tribunal pada 2016 lalu ketika memutuskan sengketa ini, keputusan hukum semacam itu tidak mungkin menghentikan ketegasan RRT di LCS, kecuali jika mereka dipasangkan dengan tindakan di bidang lain, termasuk di bidang militer dan bahkan wilayah ekonomi.

\section{PENGARUH SIKAP TIONGKOK TERHADAP ZONA EKONOMI EKSKLUSIF INDONESIA DI LAUT NATUNA}

Seperti yang telah diuraikan pada bahasan sebelumnya bahwa RRT tidak mengakui adanya putusan tersebut, dan telah disampaikan pula bahwa mereka tidak akan melaksanakannya. Padahal kita ketahui bahwa RRT merupakan Anggota Tetap Dewan Keamanan PBB yang membawa tanggung jawab moral, politik, dan hukum untuk menciptakan perdamaian dan stabilitas di dunia dan dapat bekerja. bersama dengan damai. Selama ini RRT menggunakan pendekatan yang ambigu sehingga membuka semua opsi dalam sengketa tersebut. Pada saat yang sama RRT juga terus mengembangkan kapabilitasnya di kawasan sengketa. Inilah kemudian yang membuat sengketa semakin memanas.

28 Jurnal Penilitian Politik (Yayasan Obor Indonesia) at 30; Sahar Okhovat, University of Sydney \& Centre for Peace and Conflict Studies, The United Nations Security Council: its veto power and its reform (Sydney: Centre for Peace and Conflict Studies, The University of Sydney, 2012); Justin S Gruenberg, "An Analysis of United Nations Security Council Resolutions: Are All Countries Treated Equally" (2009) 41 Case W Res J Intl L 469.

29 PCA Case No 2013-19, supra note 9.

30 Faith accomply penulis tafsikan sebagai sebuah tindakan untuk membuat orang lain mau tidak mau menyetujui tindakan tersebut. Lebih lengkap lihat secara umum pada Dan Altman, "By Fait Accompli, Not Coercion: How States Wrest Territory from Their Adversaries" (2015) Unpubl Manuscr Dartm Coll. 
Kemajuan dalam konflik LCS dapat tercapai apabila RRT dapat menyelesaikan satu-persatu dari ketiga legal disputes yang diajukan oleh Filiphina dan menyiapkan langkah awal yaitu membentuk tim negosiasi maritim yang juga melibatkan perwakilan dari Taiwan. Dalam proses tersebut RRT juga perlu menjelaskan konsep nine dash line dalam kaitannya dengan klaim RRT terhadap LCS, karena selama ini klaim telah memunculkan berbagai penafsiran yang bertentangan dengan Hukum Internasional. ${ }^{31}$ Namun sejauh ini konsep negosiasi masih berbentuk Joint Working Group (JWG) yang terlaksana sebanyak 11 kali terakhir di Bali pada Maret 2017 lalu. Dalam konsep JWG tersebut ASEAN menjadi bagian yang terpecah, ${ }^{32}$ yakni memiliki 10 pandangan yang berbeda dalam table discussion bersama RRT yang kemudian disebut dengan eleven parties.

Indonesia sebagai non- claimant state bukan berarti perannya dikesampingkan dalam penyelesaian sengketa ini. Dalam forum JWG tersebut Indonesia vokal dalam mendorong para pihak segera menyusun dokumen DoC (Document of Conduct) untuk menstabilkan wilayah. Akibat sikap RRT yang masih keras dan cenderung tidak membahas pembentukan CoC (Code of Conduct) sebagai tindak lanjut dari DoC pada beberapa pertemuan. Selain perbedaan persepsi mengenai bagaimana bentuk dan suasana forum pembahasan CoC, jika kita lihat dari sudut komitmen, dalam DoC memang sebuah komitmen yang lemah. ${ }^{33}$ Oleh karena itu, DoC akan akan menjadi ajang untuk mengulur negosiasi. Karena DoC tidak mampu mengatur pihak - pihak yang berselisih Seperti yang telah terjadi pada forum ini yakni dari JWG pertama pada 2005 yang diadakan di Manila, Filipina, hingga sekarang membutuhkan waktu yang tidak sebentar. Oleh karena itu diperlukan adanya CoC untuk menindaklanjuti DoC. Namun, sampai saat ini pembahasan $\mathrm{CoC}$ pun masih belum menemui titik terang. Para pihak yang bersengketa masih belum mampu menyepakati CoC. Namun RRT mulai mendekatkan diri untuk menyetujui penyusunan CoC pada pertemuan JWG lalu di bulan Maret 2017. Meski tetap belum ada kesepakatan mengenai bagaimana isi yang akan diatur dalam dokumen tersebut, namun setidaknya sudah ada kesepakatan untuk menyusunnya.

Meski putusan PCA dianggap oleh RRT sebagai null and void ${ }^{34}$ dan hasil keputusan ini ditolak secara keseluruhan oleh RRT. Hal ini sedikit banyak memiliki implikasi terhadap Indonesia, terutama di kawaasan Laut Natuna. Dari lima belas tuntutan yang diajukan Filipina, setidaknya ada 2 (dua) hal yang memiliki implikasi langsung terhadap Indonesia yaitu tentang status nine dash line dan status fitur maritim di kawasan LCS.

31 PCA Case No 2013-19, supra note 9.

32 Lihat Arundhati, supra note 7 at 98.

33 Agus Haryanto \& Arry Bainus, "Implikasi Declaration of Conduct Laut Tiongkok Selatan Tahun 2002 Terhadap Proses Penyelesaian Sengketa" (2017) 24:1 J Media Huk 88; Kenneth W Abbot et al, "The Concept of Legalization. International Organisation" (2003) 54:3 Camb Press 401.

34 Istilah null and void bermakna putusan tersebut adalah batal demi hukum. Lihat pernyataan Tiongkok pada Position Paper of the People's Republic of China note 112. Utrecht berpendapat mengenai nietigheid van rechtswege atau batal demi hukum adalah hukum menganggap bahwa suatu perbuatan sebagian atau keseluruhan yang ada dalam substansi putusan tersebut tidak pernah ada. 
Dengan adanya Putusan PCA tersebut, Indonesia dapat menjadikannya sebagai dasar untuk bahan pernyataan sikap dan mempersiapkan kebijakan strategis terkait. Di samping itu, Indonesia memiliki hak berdaulat di kawasan Laut Natuna. Sebelum adanya putusan PCA tersebut kapal-kapal nelayan RRT telah sering melakukan penangkapan ikan di kawasan Laut Natuna yang mereka sebut-sebut sebagai kawasan traditional fishing ground ${ }^{35}$ RRT, namun setelah adanya putusan maka semakin jelas RRT tidak memiliki hak untuk melakukan klaim serta aktifias traditional fishing ground tersebut.

Pada kesempatan yang sama, kunjungan Amerika Serikat di kawasan Asia Pasifik pada waktu lalu memberikan sebuah penawaran baru. Presiden Donald Trump menawarkan diri untuk menjadi mediator konflik atas sengketa Laut China Selatan yang masih tidak kunjung menemukan titik akhir. Kemudian kebijakan presiden Donald Trump tersebut merupakan kebijakan populis nasionalistik untuk memproteksi kepentingan AS dari segala bentuk ancaman. Namun negara kawasan tidak menanggapi karena sengketa ini harus diselesaikan oleh masing-masing pihak tanpa campur tangan pihak luar. Meskipun kebijakan dari presiden negara adidaya tersebut mempengaruhi stabilitas keamanan kawasan, namun negara kawasan tetap akan menyelesaikan sengketa ini tanpa tawaran tersebut. Karena upaya Tiongkok di Laut China Selatan dianggap oleh Amerika setara dengan upaya Rusia merebut Krimea dari Ukraina. ${ }^{36}$ Trump menyatakan bahwa Amerika Serikat tidak terikat dengan kebijakan One China Policy. Dalam hal ini Amerika Serikat di bawah Presiden Trump akan menempuh cara unilateralisme, yaitu bertindak secara sepihak demi kepentingannya. ${ }^{37}$

Di sisi lain, Donald Trump memiliki slogan berupa American First, dimana slogan ini menjadi kebijakan Amerika dalam hubungan luar negeri. American First sendiri berisi paparan bagaimana kepentingan Amerika harus didahulukan. ${ }^{38}$ secara tidak langsung, langkah ini disebut sebagai politik Amerika yang menuai pro dan kontra. Sebagaimana

35 Dalam Hukum Internasional diatur mengenai traditional fishing rights yakni hak-hak tradisional dalam melakukan aktifitas penangkapan ikan di wilayah laut yang merupakan kawasan negara lain. Untuk penentuan batas-batas wilayah penangkapan tersebut perlu dilakukan kesepakatan bilateral dengan negara yang bersangkutan. Hak tersebut tidak boleh dialihkan ke atau dibagi dengan Negara ketiga atau warga negaranya. Seperti yang telah dilakukan oleh Pemerintah Indonesia dengan Australia melalui Memorandum of Understanding tentang penangkapan ikan oleh nelayan Indonesia di kawasan ZEE dan Zona Tambahan Australia. Lihat Pasal 51 dan pasal 62 ayat (3) pada United Nation Convention on the Law of the Sea 1982, supra note 13; Akhmad Solihin, "Hak Ekonomi Nelayan Tradisional Indonesia Di Wilayah Perbatasan" (2011) 317 Opinio Juris J Huk Dan Perjanjian Int; Ganewati Wuryandari, “Menerobos Batas' Nelayan Indonesia di Perairan Australia: Permasalahan dan Prospek” (2016) 11:1 J Penelit Polit 20.

36 metrotvnews developer, "Menlu Pilihan Trump Larang Tiongkok Masuk ke Laut China Selatan", metrotvnews.com, online: 〈http://internasional.metrotvnews.com/amerika/VNxJD0lk-menlu-pilihantrump-larang-tiongkok-masuk-ke-laut-china-selatan〉.

37 Adirini Pujayanti, "Kebijakan Imigrasi Pemerintahan Presiden Donald Trump", Maj Info Singk Hub Int (February 2017), online: 〈http://berkas.dpr.go.id/puslit/files/info_singkat/Info\%20Singkat-IX-1-IP3DI-Februari-2017-179.pdf>.

38 The Jakarta Post, "Isolated US lashes out at climate critics", Jkt Post, online: 〈http://www.thejakartapost.com/news /2017/06/03/isolated-us-lashes-out-at-climate-critics.html〉. 
diketahui bersama, politik dalam dunia internasional, sama halnya dengan semua politik yang bermuara pada sebuah kekuasaan. Konsep ini sendiri terbagi menjadi dua. Kesatu, tidak setiap tindakan yang dilakukan suatu negara yang berhubungan dengan negara lain bersifat politik. Misalnya dalam memberikan bantuan bencana alam. Kedua, tidak semua negara senantiasa terlibat dalam taraf yang sama dalam politik internasional. Artinya, politik dalam hubungan internasional bersifat dinamis. Hubungan ini dapat berubah apabila terjadi pergantian kekuasaan. ${ }^{39}$ Secara tidak langsung, kebijakan Amerika yang tertuang dalam American First, merupakan perlawanan terhadap kemapanan pada isu-isu globalisasi, perdagangan bebas, dan imigrasi yang merupakan konsensus elite politik sebelumnya namun tidak memuaskan publik AS.

Menilik fakta di atas, slogan American First dapat mempengaruhi kebijakan Amerika dalam mengutamakan kepentingannya di kawasan Laut China Selatan. Sehingga, secara tersirat, terdapat dua kekuatan negara besar yang memiliki kepentingan, yaitu Tiongkok dan Amerika. Dan keadaan inilah yang menjadi salah satu faktor mengapa negara anggota ASEAN tidak memiliki persamaan pandangan dalam penyelesaian sengketa Laut China Selatan.

Terkait perbedaan pandangan negara anggota ASEAN dan dengan adanya putusan PCA, Indonesia mengumumkan penamaan kawasan yang terletak di ujung selatan LCS dengan nama Laut Natuna Utara. ${ }^{40}$ Langkah tersebut merupakan bagian dari peresmian peta nasional yang diperbaharui setelah memakan waktu berbulanbulan dalam pembuatannya. Pembaruan tersebut tak lain adalah mencerminkan tekad negara Asia Tenggara untuk melindungi klaimnya bahkan di tengah tantangan yang melekat dalam melakukan tekad tersebut.

Meskipun Indonesia bukan claimant state yang menuntut secara kuat atas wilayah di kawasan, namun Indonesia tetap menjadi pihak yang berkepentingan, terutama sejak klaim nine dash line tumpang tindih dengan zona ekonomi eksklusif Indonesia (ZEE) di sekitar Kepulauan Natuna yang kaya sumber daya alam. Dengan adanya pembaruan peta tersebut, maka secara langsung Pemerintah Indonesia tidak mengakui klaim garis nine dash line di hadapan RRT. ${ }^{41}$

39 Hans J Morgenthau and Kenneth W Thompson, Politik Antarbangsa (Yayasan Pustaka Obor Indonesia) hlm 34 .

40 Pendaftaran nama pulau serta kawasan lain yang berkaitan merupakan upaya pemerintah Indonesia untuk melaksanakan tanggungjawabnya serta menjaga keutuhan dan keamanan sebagai negara kepulauan. Meskipun hasil verifikassi PBB bukan merupakan ketetapan atas kepemilikan pulau, namun verifikasi tersebut menjadi dasar hukum yang kuat untuk klaim kepemilikan yang sah, serta sebagai upaya baru untuk melakukan penataan terhadap pemanfaatan pulau-pulau kecil yang kita miliki karena proses penamaan yang dikerjakan lintas kementerian dan lembaga itu sesuai dengan standar yang ditetapkan International Hidrographic Organization (IHO) dan ketentuan Electronic Navigational Chart. Lebih lengkap lihat "PBB Verifikasi 16.056 Nama Pulau Indonesia", online: 〈http://setkab.go.id/pbb-verifikasi-16-056-nama-pulau-indonesia/`.

41 “Mengapa pemerintah Indonesia mendaftarkan 1.700 'pulau baru' ke PBB?", BBC Indones (6 June 2017), online: 〈http://www.bbc.com/indonesia/indonesia-40155730); BBC Indonesia, "China Komentari Penamaan Laut Natuna Utara oleh Indonesia", online: detiknews 
Laut Natuna Utara hanyalah yang terbaru dari serangkaian peruntukan nama untuk wilayah-wilayah di sekitar kawasan yang telah kita ketahui di antara negaranegara Asia Tenggara. Filipina mengacu pada putusan tribunal, menamai wilayah yang tumpang tindih dengan klaim RRT dengan nama Laut Filipina Barat, dan Vietnam menyebutnya sebagai Laut Timur. ${ }^{42}$

Seperti pada kasus-kasus lain, dari perspektif Indonesia, kejelasan itu lebih dari sekedar makna simbolis. Karena pemerintah Indonesia mulai mendaftarkan nama baru kepada International Hydrographic Organization (IHO), langkah tersebut akan membawa dampak yang lebih luas dan akan sangat penting untuk memastikan bahwa tindakannya sesuai dengan hukum internasional. ${ }^{43}$ Dalam hal tersebut, bukanlah menjadi suatu kebetulan bahwa pemerintah Indonesia secara langsung menyebutkan putusan tribunal sebagai alasan untuk mengganti namanya. Pemerintah mencoba mendasarkan perubahan domestik sebagian karena kepatuhan terhadap hukum internasional. $^{44}$ Di samping itu, dengan jelas bahwa yang dilakukan pemerintah Indonesia tersebut berkenaan dengan tingkat batas negara-negara Asia Tenggara yang juga memiliki alasan praktis mengenai sumber minyak dan gas yang berada di bawah landas kontinen serta legalitas tindakan lain yang dapat dilakukan untuk mencapai kekuatan klaimnya, termasuk patroli laut.

Masuknya daftar alasan untuk peta baru, bukan hanya Natuna saja, tidak diragukan lagi memiliki utilitas diplomatik tersendiri. Namun pada saat yang sama, meskipun hal ini sering tidak mendapat banyak perhatian di kalangan pengamat luar. Pemerintah telah membuat kemajuan dalam masalah perbatasan yang menonjol dengan negara-negara tetangga. ${ }^{45}$ Sebagai prioritas utama sejak awal, yang terkait dengan penekanan yang lebih luas pada pengamanan kedaulatan dan integritas territorial, dan yang paling terlihat yakni dimanifestasikan dengan meledakkan kapal penangkap ikan ilegal.

Perspektif yang lebih luas harus diingat karena perkembangan ini terungkap, dan bukan fokus eksklusif pada RRT dan LCS. Dalam kasus lain yakni perundingan batas ntara Indonesia dan Filipina yang juga menyangkut batas maritim di kawasan LCS. Meskipun ada perbedaan bentuk antara garis persegi panjang Perjanjian Paris yang sebelumnya digunakan Filipina dengan Indonesia dan sembilan garis pantai yang saat ini digunakan RRT untuk mendasarkan klaim maritimnya di LCS, mereka memiliki satu kesamaan, yakni keduanya merupakan ungkapan klaim sepihak yang tidak didasarkan pada hukum internasional. Oleh karena itu, eskalasi dalam klaim yang

〈https://news.detik.com/read/2017/07/15/134410/3561255/934/ china-komentari-penamaan-lautnatuna-utara-oleh-indonesia>.

42 Prashanth Parameswaran Diplomat The, "Why Did Indonesia Just Rename Its Part of the South China Sea?", The Diplomat, online: 〈https://thediplomat.com/2017/07/why-did-indonesia-just-renameits-part-of-the-south-china-sea/>.

43 Indonesia note 142; Diplomat note 143.

44 Damos Dumoli Agusman, "Indonesia dan Hukum Internasional: Dinamika Posisi Indonesia Terhadap Hukum Internasional” (2014) 1517 Opinio Juris J Huk Dan Perjanjian Int.

45 Lihat secara umum pada Poltak Partogi Nainggolan, "Kebijakan Poros Maritim Dunia Joko Widodo dan Implikasi Internasionalnya" (2016) 6:2 J Polit Trial. 
tumpang tindih di LCS bukanlah norma regional. Mereka adalah anomali terhadap praktik negara yang ada di Asia Tenggara dan harus diperbaiki.

Asia dapat menjadi pemimpin dunia dalam pencegahan dan pengelolaan konflik sengketa terlepas dari adanya batasan-batasan. Hal ini dapat dilakukan dengan menempatkan kepentingan bersama dan kepentingan publik yang lebih besar, yaitu stabilitas dan keamanan regional, di atas pandangan nasional yang sempit.

\section{KESIMPULAN}

Akibat hukum putusan Mahkamah Arbitrase Tetap Internasional nomor 2013-19 tahun 2016 yang melibatkan RRT dan Filipina dalam sengketa Laut China Selatan yakni memberikan klarifikasi mengenai status pulau, karang, dan hal-hal yang telah disebutkan dalam UNCLOS; memberikan kejelasan bahwa nine dash line dan aktifitas RRT di Laut China Selatan tidak sesuai dengan kaidah-kaidah hukum Internasional yang berlaku; namun kekuatan dari putusan tribunal tersebut membuat RRT tetap bersikeras akan posisinya di Laut China Selatan sehingga memutuskan untuk tidak mengakui dan tidak mematuhi putusan tersebut.

Konsekuensi ketidakpatuhan RRT terhadap Zona Ekonomi Eksklusif Indonesia di Laut Natuna yakni menimbulkan tumpang tindih kawasan Zona Ekonomi Eksklusif Indonesia di Laut Natuna dengan wilayah yang di klaim RRT melalui nine dash line; namun demikian dengan adanya putusan tribunal tersebut Indonesia dapat menjadikannya sebagai dasar pernyataan sikap dan mempersiapkan kebijakan strategis terkait.

Putusan arbitrase akan membawa kepentingan yang signifikan, karena akan menjadi sumber hukum internasional. Ketentuan tersebut didasarkan pada Pasal 38 Statuta ICJ, bahwa keputusan pengadilan adalah sumber hukum internasional. Substansi tersebut mungkin juga membawa beberapa elemen dasar hukum internasional seperti definisi istilah "tempat tinggal manusia" dan istilah "kehidupan ekonomi mereka sendiri" yang dapat disebut oleh pengadilan internasional di masa depan. Pada saat itu, akan sulit bagi RRT untuk menentang keputusan tersebut. Jika RRT menerima keputusan arbitrase, hal tersebut tidak berarti bahwa RRT membatalkan klaimnya atas fitur maritim di LCS. Mereka dapat menyesuaikan klaimnya dengan hanya menggambar zona maritim dari semua fitur yang diklaimnya dalam jarak 12 atau 200 mil laut sesuai dengan keputusan arbitrase. Dengan posisi ini, RRT bisa meminta penggugat lainnya yaitu Filipina, Brunei, Vietnam dan Malaysia untuk mengklarifikasi klaim masing-masing. Dengan menerima arbitrase dan putusannya, RRT dapat mengatasi kesulitan yang dihadapi saat ini dan menjadikannya sebagai kesempatan yang baik untuk membangun stabilitas di kawasan tersebut.

Hal yang perlu dipertimbangkan kembali oleh RRT yakni ketika menjadi salah satu pihak dalam suatu perjanjian akan tetapi tidak berpartisipasi dalam proses sengketa, maka akan merugikan posisi internasionalnya. Sebagai anggota tetap Dewan Keamanan PBB dan juga sebagai negara yang selalu memiliki hakim yang duduk di 
ITLOS, ICJ, maupun pengadilan internasional lainnya, RRT perlu memberikan contoh bahwa penyelesaian melalui mekanisme sengketa internasional adalah yang terbaik.

Indonesia telah melakukan langkah terbaik untuk mengajukan verifikasi namanama pulau kepada IHO serta memberikan nama di laut sekitar Natuna dengan nama Laut Natuna Utara seperti halnya Laut Natuna Selatan dan mengesahkan peta nasional untuk memperkuat klaim sesuai dengan Hukum Internasional. Namun kita perlu juga untuk: meneguhkan jati diri bangsa untuk menjaga keamanan nasional; menyediakan data baik secara tekstual maupun geospasial terkait wilayah negara; peningkatan pengawasan dan pengamanan di pulau-pulau kecil terdepan, dan terisolasi; meningkatkan kualitas pendidikan maritim yang baik; serta penguasaan dan pemanfaatan IPTEK dan juga yang sangat pokok yakni menyelesaikan sengketa batas maritim Indonesia dengan negara tetangga.

\section{DAFTAR PUSTAKA}

Abbot, Kenneth W et al. "The Concept of Legalization. International Organisation" (2003) 54:3 Camb Press 401.

Agusman, Damos Dumoli. "Indonesia dan Hukum Internasional: Dinamika Posisi Indonesia Terhadap Hukum Internasional" (2014) 1517 Opinio Juris J Huk Dan Perjanjian Int.

Altman, Dan. "By Fait Accompli, Not Coercion: How States Wrest Territory from Their Adversaries" (2015) Unpubl Manuscr Dartm Coll.

Arundhati, Gautama Budi. "Dinamika Relasi Antara Prinsip Non Interference dan Prinsip Solidaritas ASEAN" (2017), online: 〈http://repository.unej.ac.id/handle/ 123456789/79234>.

BBC Indonesia, "Mengapa pemerintah Indonesia mendaftarkan 1.700 'pulau baru' ke PBB?", BBC Indones (6 June 2017), online: 〈http://www.bbc.com/indonesia/indonesia-40155730〉.

Charter of the United Nations, U N Charter, 1945 [UN Charter].

Detik.com. "China Komentari Penamaan Laut Natuna Utara oleh Indonesia", online: detiknews 〈http://news.detik.com/read/2017/07/15/134410/3561255/934/chinakomentari-penamaan-laut-natuna-utara-oleh-indonesia>.

Gruenberg, Justin S. “An Analysis of United Nations Security Council Resolutions: Are All Countries Treated Equally" (2009) 41 Case W Res J Intl L 469.

Haryanto, Agus \& Arry Bainus. "Implikasi Declaration of Conduct Laut Tiongkok Selatan Tahun 2002 Terhadap Proses Penyelesaian Sengketa” (2017) 24:1 J Media Huk 88.

Janis, Mark Weston. "The Hague Peace Conferences of 1899 and 1907 and International Arbitration: Reports and Documents" (2002) 49:2 Neth Int Law Rev 290.

Maritime Zone of Northeast Asia, CIA-RPD08C01297R000200130003-5 (Bureau of Intelligence and Research of Central Intelligence Agency US, 2012). 
Matsumura, Masahiro. "San Francisco Treaty and the South China Sea", Jpn Times (13 October 2013), online: 〈https://www.japantimes.co.jp/opinion/2013/10/13/ commentary/world-commentary/san-francisco-treaty-and-the-south-china-sea/s.

Metrotvnews. "Menlu Pilihan Trump Larang Tiongkok Masuk ke Laut China Selatan”, metrotvnews.com, online: 〈http://internasional.metrotvnews.com/amerika/VNxJD0lk-menlu-pilihantrump-larang-tiongkok-masuk-ke-laut-china-selatan>.

Morgenthau, Hans J \& Kenneth W Thompson. Politik Antarbangsa (Yayasan Pustaka Obor Indonesia, 2006).

Nainggolan, Poltak Partogi. "Kebijakan Poros Maritim Dunia Joko Widodo dan Implikasi Internasionalnya” (2016) 6:2 J Polit Trial.

Okhovat, Sahar, University of Sydney \& Centre for Peace and Conflict Studies. The United Nations Security Council: its veto power and its reform (Sydney: Centre for Peace and Conflict Studies, The University of Sydney, 2012).

O'Shea, Paul. "Territorial disputes in Northeast Asia: A primer" (2013) 182 Ital Inst Int Polit Stud Anal ISPI No 182.

PCA Case No 2013-19 In Matter of The South China Sea Arbitration before an Arbitral Tribunal Constituted Under Annex VII to The 1982 United Nations Convention on The Law of The Sea Between The Republic of Philippines and The People's Republic of China [PCA Case No 201319].

Position Paper of the Government of the People's Republic of China on the Matter of Jurisdiction in the South China Sea Arbitration Initiated by the Republic of the Philippines [Position Paper of the People's Republic of China].

Pujayanti, Adirini. "Kebijakan Imigrasi Pemerintahan Presiden Donald Trump”, Maj Info Singk Hub Int (February 2017), online: 〈http://berkas.dpr.go.id/puslit/files/info_ singkat/Info\%20Singkat-IX-1-I-P3DI-Februari-2017-179.pdf〉.

Ridderhof, R. "The South China Sea Arbitration (12 July 2016) PCA Case No. 2013-19 | Peace Palace Library", (22 July 2017), online: <//www.peacepalacelibrary.nl/2016/07/ pca-award-south-china-sea-12-july-2016/>.

Scott, James Brown. The Hague Court Reports [1st]-2nd Series: Comprising the Awards, accompanied by Syllabi, the Agreements for Arbitration, and Other Documents in Each Case Submitted to the Permanent Court of Arbitration and to Commissions of Inquiry Under the Provisions of the Conventions of 1899 and 1907 for the Pacific Settlement of International Disputes (Oxford University Press, American branch, 1916).

Sekretariat Kabinet Republik Indonesia "PBB Verifikasi 16.056 Nama Pulau Indonesia”, online: 〈http://setkab.go.id/pbb-verifikasi-16-056-nama-pulau-indonesia/〉.

Setianingsih Suwardi, Sri. Penyelesaian Sengketa Internasional (Jakarta: UI-Press, 2006).

Snyder, Scott \& See-Won Byun. "Cheonan And Yeonpyeong: The Northeast Asian Response to North Korea's Provocations” (2011) 156:2 RUSI J 74.

Solihin, Akhmad. "Hak Ekonomi Nelayan Tradisional Indonesia Di Wilayah Perbatasan" (2011) 317 Opinio Juris J Huk Dan Perjanjian Int. 
Talmon, Stefan \& Bing Bing Jia. The South China Sea Arbitration: A Chinese Perspective (Bloomsbury Publishing, 2014).

The Diplomat, "Why Did Indonesia Just Rename Its Part of the South China Sea?", The Diplomat, online: 〈https://thediplomat.com/2017/07/why-did-indonesia-justrename-its-part-of-the-south-china-sea/s.

The Jakarta Post. "How China can benefit from the S. China Sea arbitration - Opinion The Jakarta Post", online: 〈http://www.thejakartapost.com/academia/2016/06/16/ how-china-can-benefit-from-the-s-china-sea-arbitration.html.

The Jakarta Post. "Isolated US lashes out at climate critics", Jkt Post, online: 〈http://www.thejakartapost.com/news/2017/06/03/isolated-us-lashes-out-atclimate-critics.html>.

United Nations. "Chronological lists of ratifications of", online: 〈http://www.un.org/ depts/los/reference_files/chronological_lists_of_ratifications.htm〉.

United Nation Convention on the Law of the Sea 1982 [United Nation Convention on the Law of the Sea 1982].

Wuryandari, Ganewati. “Menerobos Batas' Nelayan Indonesia di Perairan Australia: Permasalahan dan Prospek” (2016) 11:1 J Penelit Polit 20. 